\title{
PERLINDUNGAN DATA REKAM MEDIS SEBAGAI BENTUK PERLINDUNGAN DATA PRIBADI PASIEN SELAMA PANDEMI COVID-19
}

\author{
Alfian Listya Kurniawan \\ Anang Setiawan ${ }^{1 凶}$ \\ ${ }^{1}$ Magister Hukum, Fakultas Hukum Universitas Sebelas Maret, Surakarta, Indonesia \\ Jln. Ir. Sutami, No. 36A, Surakarta, Jawa Tengah 57126- Phone 0271-642595 \\ $\triangle$ Burhannudin.bi@gmail.com, anangsetiawan1479@gmail.com
}

\begin{abstract}
This study aims to analyze the efforts made by the government in order to protect personal data, especially related to patient medical records. In the midst of the rampant Corona Virus Disease-19 (hereinafter referred to as Covid 19) pandemic in Indonesia. Often the identity of the patient or person who has been exposed to Covid 19 is known by the community in their environment, which has implications for the isolation of the patient from the surrounding community. There are also frequent leaks of the identity of Covid-19 patients in the surrounding community due to information coming out of the hospital with the aim of preventing the spread of the virus which basically violates the provisions regarding the privacy of patients with Covid 19. suffered by someone is also widely spread to the public. Based on this, it is necessary to study how the government should regulate the protection of medical records in the future, especially regarding the current Covid-19 pandemic.
\end{abstract}

Keywords: Medical records, Personal Data Protection, Covid-19.

Kajian ini bertujuan untuk menganalisa upaya yang dilakukan pemerintah dalam rangka melindungi data pribadi khususnya terkait dengan rekam medis pasien. Ditengah maraknya pandemi Corona Virus Disease-19 (Selanjutnya disebut dengan Covid 19) di Indonesia. Seringkali identitas penderita atau orang yang telah terpapar Covid 19 diketahui oleh masyarakat di lingkunganya, yang berimplikasi pada diasingkannya penderita tersebut dari masyarakat sekitar. Sering terjadi juga bocornya identitas pasien Covid-19 dimasyarakat lingkungan sekitar yang diakibatkan informasi yang keluar dari pihak rumah sakit dengan tujuan pencegahan penyebaran virus tersebut yang pada dasarnya melanggar ketentuan mengenai privasi pasien penderita Covid 19, lebih buruk sering kali data rekam medis lain termasuk penyakit yang diderita seseorang ikut tersebar luas ke publik. Berdasarkan hal tersebut perlu dijaki bagaimana seharusnya pengaturan mengenai perlindungan terhadap rekam medis kedepannya terlebih terkait pandemi Covid 19 saat ini.

Kata Kunci: Rekam Medis, Perlindungan Data Pribadi, Covid-19. 


\section{INTRODUCTION}

Dalam pelayanan kesehatan, rekam medis sangat melekat dalam kegiatan pelayanan kesehatan, sehingga ada ungkapan rekan medis merupakan pihak ketiga pada saat dokter menerima pasien. Hal ini dapat dipahami karena rekam medis merupakan catatan pemeriksaan dan tindakan yang terkait dengan penanganan pasien oleh dokter. Rekam medis merupakan berkas yang berisikan catatan dan dokumen tentang identitas pasien, pemeriksaan, pengobatan, tindakan, dan pelayanan lain yang telah diberikan kepada pasien. Rekam medis adalah kumpulan keterangan tentang identitas, hasil anamnesis, pemeriksaan dan catatan segala kegiatan para pelayan kesehatan atas pasien dan dari waktu-kewaktu. ${ }^{1}$

Meminjam pandangan dari Gemala R. Hatta dalam makalahnya yang berjudul "Peranan Rekam Medik Kesehatan/Pasien (medical record) dalam Hukum Kedokteran", menyatakan bahwa:

"Rekam medis dirumuskan sebagai kumpulan segala kegiatan yang dilakukan oleh para pelayan kesehatan yang ditulis, digambarkan, atas aktivitas terhadap pasien. Rekam medis harus dibuat secara tertulis, lengkap dan jelas atau secara elektronik".

Rekam medik adalah keterangan baik tertulis maupun rekaman tentang indentitas, anamnesis, penentuan fisik, pemeriksaan laboratorium/radiologi, diagnosis, segala pelayanan dan tindakan medis yang diberikan kepada pasien baik pelayanan rawat jalan, rawat inap,maupun pelayanan gawat darurat yang diberikan kepada pasien. Menurut Kementerian Kesehatan rekam medis sangat penting dalam mengukur mutu pelayanan medis yang diberikan oleh rumah sakit beserta staf medisnya. Salah satu parameter untuk menentukan mutu pelayanan kesehatan di rumah sakit adalah data atau informasi dari rekam medis yang baik dan lengkap. Indikator mutu rekam medis yang baik adalah kelengkapan isi, akurat, tepat waktu dan pemenuhan aspek persyaratan hukum. Dalam hal terjadi kesalahan dalam melakukan pencatatan pada rekam medis, berkas dan catatan tidak boleh dihilangkan atau dihapus dengan cara apapun. Perubahan catatan atau kesalahan dalam rekam medis hanya dapat dilakukan dengan pencoretan dan dibubuhi paraf petugas yang bersangkutan. Kegunaan rekam medis secara umum meliputi: ${ }^{2}$

1. Sebagai alat komunikasi antar dokter dengan tenaga ahli lainnya yang ikut ambil bagian di dalam memberikan pelayanan, pengobatan dan perawatan kepada pasien.

2. Sebagai dasar untuk merencanakan pengobatan/perawatan yang harus diberikan pada seorang pasien.

3. Sebagai bukti tertulis atas segala tindakan pelayanan, perkembangan penyakit dan pengobatan selama pasien berkunjung/dirawat di rumah sakit.

4. Sebagai bahan yang berguna untuk analisa, penelitian dan evaluasi terhadap kualitas pelayanan yang diberikan kepada pasien.

5. Melindungi kepentingan hukum bagi pasien, rumah sakit maupun dokter dan tenaga kesehatan lainnya.

\footnotetext{
${ }^{1}$ Frenti Giyana, 'Analisis Sistem Pengelolaan Rekam Medis Rawat Inap Rumah Sakit Umum Daerah Kota Semarang', Jurnal Kesehatan Masyarakat Universitas Diponegoro, 1.2 (2012), 18739.

2 Gunawa Susanto, 'Sistem Informasi Rekam Medis Pada Rumah Sakit Umum Daerah (RSUD) Pacitan Berbasis Web Base', Speed-Sentra Penelitian Engineering Dan Edukasi, 3.4 (2012).
} 
6. Menyediakan data-data khusus untuk keperluan penelitian dan pendidikan.

7. Sebagai dasar di dalam perhitungan biaya pembayaran pelayanan medis pasien.

8. Menjadi ingatan yang harus didokumentasikan serta bahan pertanggung jawaban dan laporan.

Selain 8 (delapan) butir poin yang penulis paparkan di atas, pemanfaatan rekam medis dapat dipakai sebagai: ${ }^{3}$

1. Pemeliharaan kesehatan dan pengobatan pasien.

2. Alat bukti dalam proses penegakan hukum, disiplin kedokteran dan kedokteran gigi dan penegakan etika kedokteran dan etika kedokteran gigi.

3. Keperluan pendidikan dan penelitian.

4. Dasar pembayar biaya pelayanan kesehatan.

5. Data statistik kesehatan.

Adapun tindakan lembaga/sarana pelayanan kesehatan yang harus dicatat di dalam Medical Records pasien adalah mengenai identitas pasien, pemeriksaan, pengobatan, tindakan dan pelayanan lain kepada pasien. Jadi didalam Medical Records itu akan memuat juga jenis pasien bahkan riwayat penyakit keluarga pasien yang menjadi acuan penyembuhan penyakit pasien yang ada kaitannya dengan penyakit keturunan misalnya. Maka artinya rahasia pasien dan keluarga pasien ada didalammnya. Rahasia itu adalah milik pasien yang merupakan isi berkas Medical Records yang dibuat tenaga kesehatan yang merawatnya baik rawat jalan maupun rawat inap. Karena itu untuk melindungi rahasia penyakit pasen itu pada mulanya diatur di dalam Permenkes Nomor 749a/ Tahun 1989, yang kemudian juga diatur dalam Pasal 47 Ayat (1) Undang-Undang Nomor 29 Tahun 2004 Tentang Praktik Kedokteran dan Permenkes Nomor 269 Tahun 2008 Tentang Rekam Medis yang di dalamnya dinyatakan bahwa berkas rekam medis secara fisik merupakan milik Sarana Pelayanan Kesehatan (Saryankes) dan isi berkas rekam medis merupakan milik pasien. ${ }^{4}$ Selanjutnya berkaitan dengan sifat rahasia isi Medical Records terdapat beberapa hak yang merupakan manifestasi yuridis sifat rahasia itu antara lain:

1. Hak Privacy

2. Hak Akses Pasien

3. Hak Atas Rahasia Kedokteran

4. Hak Tolak Ungkap Rahasia Kedokteran.

Berikut penulis paparkan ke 4 (empat) aspek hak yang menaungi rekam medis dalam manifestasi yuridis terkait sifat kerahasiaanya tersebut. Pertama, hak privasi Menurud Fred Ameln, Hak Privacy adalah suatu hak pribadi, suatu hak atas kebebasan atau keleluasaan pribadi yang bersumber dari "The Right to Self Determination (TROS)". Inti hak itu adalah hak untuk menentukan sendiri atas diri (badan) yang tidak boleh diganggu atau yang lebih

\footnotetext{
${ }^{3}$ Wijiatmo and Supanto, 'Kebijakan Hukum Pidana Dalam Memberikan Perlindungan Hukum Terhadap Guru Dalam Hal Kedisplinan', Pasca Sarjana Hukum UNS, 7.1 (2019), 85-92.

4 C.D. Balenina, 'Partisipasi Masyarakat Dalam Pengelolaan Desa Sampah Mandiri Di Desa Kalisoro,

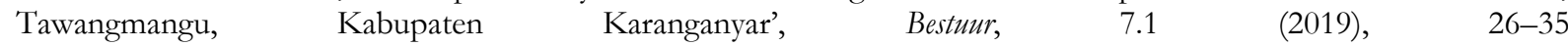
$<$ https://jurnal.uns.ac.id/bestuur/article/view/17392>.
} 
spesifik adalah "A right to be free from unwanted publicity". Adapun Hak Privacy itu antara lain bersumber pada: ${ }^{5}$

1. Konvensi-Konvensi Internasional a. Pasal 12 Universal Declaration of Human Rights b. Pasal 17 international Convenan on civil and Political Rights 1946 c. Butir 6 Hospital Patients Charter, 1979.

2. Undang-Undang Dasar 1945

3. Undang-Undang Nomor 29 Tahun 2004 tentang Pratik Kedokteran (Selanjutnya disebut UU Praktik Kedokteran).

Dalam hubungan dokter-pasien yang mengandung unsur kepercayaan bahwa dokter mampu memberikan pelayanan medis dan mampu dipercaya untuk menyimpan rahasia kedokteran mengenai penyakit pasien dan hal-hal lain yang sifatnya Privacy. Dalam hal ini dokter memikul kewajiban secara etika profesi (Sumpah Profesi Dokter) sekaligus kewajiban hukum dari ketentuan perundang-undangan di atas untuk menjaga kerahasian isi Medical Records pasiennya, sebagaimana diatur dalam Pasal 51 UU Praktik Kedoteran yang memuat kewajiban dokter atau dokter gigi dalam melaksanakan praktik kedokteran, yakni: 6

1. memberikan pelayanan medis sesuai dengan standar profesi dan standar prosedur operasional serta kebutuhan medis pasien;

2. merujuk pasien ke dokter atau dokter gigi lain yang mempunyai keahlian atau kemampuan yang lebih baik, apabila tidak mampu melakukan suatu pemeriksaan atau pengobatan;

3. merahasiakan segala sesuatu yang diketahuinya tentang pasien, bahkan juga setelah pasien itu meninggal dunia;

4. melakukan pertolongan darurat atas dasar perikemanusiaan, kecuali bila ia yakin ada orang lain yang bertugas dan mampu melakukannya; dan

5. menambah ilmu pengetahuan dan mengikuti perkembangan ilmu kedokteran atau kedokteran gigi.

Pada butir ke 3 (tiga) Pasal 51 UU Praktik Kedokteran tersebut terang dan jelas dikatakan bahwa dokter wajib merahasiakan segala sesuatu yang diketahuinya tentang pasien bahkan setelah pasien tersebut meninggal dunia, hal tersebut sejalan dengan pasal 47 UU Praktik Kedokteran yang mengatur mengenai rekam medis yang menyatakan bahwa: ${ }^{7}$

1. Dokumen rekam medis sebagaimana dimaksud dalam Pasal 46 merupakan milik dokter, dokter gigi, atau sarana pelayanan kesehatan, sedangkan isi rekam medis merupakan milik pasien.

2. Rekam medis sebagaimana dimaksud pada ayat (1) harus disimpan dan dijaga kerahasiaannya oleh dokter atau dokter gigi dan pimpinan sarana pelayanan kesehatan.

\footnotetext{
${ }^{5}$ Eni Muryani, 'Sinergisitas Penegakan Hukum Pada Kasus Pertambangan Emas Tanpa Izin Di Kabupaten Banyumas, Jawa Tengah', Bestuur, 7.2 (2019), 84 <https://doi.org/10.20961/bestuur.v7i2.40437>.

${ }^{6}$ Yatini, Hari Purwadi, and Hartiwiningsih, 'Reformulasi Konstruksi Pidana Dalam Menjerat Pelaku Tindak Pidana Korporasi', Pasca Sarjana Hukum UNS, VII.1 (2019), 144-52.

${ }^{7}$ Riyan Aditya Nugraha, Widodo Tresno Novianto, and Supanto, 'KARANGANYAR DALAM MEMUTUS PERKARA PIDANA HAK CIPTA GUNA MENCIPTAKAN KEPASTIAN HUKUM CIPTA ( Putusan', Jurnal Pasca Sarjana Hukum UNS, 7.1 (2011), 169-80.
} 
3. Ketentuan mengenai rekam medis sebagaimana dimaksud pada ayat (1) dan ayat (2) diatur dengan Peraturan Menteri.

Maka dapat dikatakan bahwa pada bagian tersebut korelasi rekam medis sebagai hak privacy dari pasien yang wajib dijaga kerahasiaanya oleh dokter ataupun dokter gigi, dengan konsekuensi apabila hal tersebut dilanggar maka dokter harus siap-siap untuk mendapat sanksi etika berdasarkan kode etik profesinya maupun sanksi berupa gugatan perdata dan/atau pidana atas kesalahannya. Terhadap kelalaian menjaga rahasia kedokteran dapat dikenai tuntutan Pasal 322 KUHPidana terkai tindakan membuka rahasia jabatan, sedangkan terhadap pelanggaran atas Hak Privacy tidak dapat dituntut secara pidana tetapi lebih cenderung sebagai suatu Onrechmatigedaad, yang dapat digugat melalui pasal 1365 KUHPerdata. $^{8}$

Kedua, Hak Akses atas Rahasia Kedokteran sebagai pemilik isi Medical Records, maka pasien secara logis-yuridis, berdasarkan ketentuan Permenkes Nomor 269 Tahun 2008 Tentang Rekam Medis memiliki akses atas isi Medical Records dengan alasan-alasan:

1. Karena data medis yang tercatat didalam rekam medis adalah data pribadi pasien merupakan kelanjutan dari pengungkapan penyakit yang diderita pasien kepada dokter, sehingga logis jika pasien ingin tahu tindakan dokter terhadap dirinya.

2. ltikad baik dokter dalam hubungan hukum berupa "Inspanningsverbintenis", dalam upaya penyembuhan penyakit pasien.

3. Hak Akses atas Rahasia Kedokteran yang ada di dalam Medical Records merupakan kelanjutan Hak Asasi Pasien dan atas dasar serta prinsip-prinsip hukum umum yang wajib dipatuhi dokter. Kalau pasien bisa mengetahui tentang penyakitnya, maka dia pun mesti boleh tahu tentang pengobatannya.

Ketiga, Hak atas Rahasia Kedokteran Istilah "Rahasia Kedokteran", terdiri dari kata 'rahasaia' dan kata 'kedokteran'. Menurut kaidah Bahasa Indonesia pola kata (istilah) itu adalah "Di'terangkan-Menerangkan ", sehingga Rahasia Kedokteran bermakna rahasia di bidang kedokteran, bukannya rahasia milik dokter seperti anggapan masyarakat awam selama ini. Dokter hanya wajib menyimpan rahasia yang dipercayakan kepadanya sebagai kewajiban profesinya sebagai salah satu profesi kepercayaan seperti yang dimiliki pastor, bankir, notaris, dan lain sebagainya. Ketentuan di dalam Permenkes Nomor 434/Men/Menkes/XI/1983 tentang berlakunya Kode Etik Kedokteran Indonesia bagi Dokter di Indonesia merupakan pedoman pelaksanaan kewajiban dokter untuk menjaga rahasia penyakit pasiennya sampai meninggal dunia sekalipun.

Keempat, Hak Tolak Ungkap (Verschoningsrecht) Rahasia Kedokteran Hak Tolak Ungkap adalah dapat diartikan sebagai suatu hak dokter untuk menolak/keberatan atas pengungkapan rahasia yang diketahui sebagai insan profesi yang memiliki esensi berupa "trust beneficiary" yang mengandung kewajiban menjaga kepercayaan yang diberikan pasien. Secara etis hal ini diatur dalam kode etik yang kemudian dikenal dengan Permenkes Nomor 434/Menkes/XX/1983 pasal 11, sedangkan ketentuan hukum lainnya yaitu berupa Pasal 332 KUHPidana yang mewajibkan dokter menjaga rahasia yang

8 Sara Hersriavita, 'UPAYA PENGEMBALIAN KERUGIAN NEGARA DARI PERKARA TINDAK PIDANA KORUPSI OLEH KEJAKSAAN NEGERI SUKOHARJO', Jurnal Hukum Dan Pembangunan Ekonomi, 7.1 (2019), 15-28. 
dipercayakan kepadanya dengan ancaman hukuman penjara maksimal 9 (sembilan) bulan atau denda paling tinggi Rp. 600 (lama). Ketentuan pasal 332 KUHPidana itu merupakan senjata bagi dokter untuk tidak melanggar kewajiban profesinya. Yang menarik dari ketentuan lainnya di dalam K UHPidana adalah Pasal 224 yang memuat ketentuan yang mengharuskan dokter untuk mengungkapkan rahasia kedokteran dalam hal kewajiban memberikan kesaksian dalam sidang pengadilan dikaitkan dengan pembuktian yang diatur dalam KUHAP pasal 187b dan 187c jo. pasal 8b dan 184c jo. pasal 14b Permenkes no. 749a/1989. Maka sah adanya terhadap pengungkapan isi Medical Records sejalan dengan doktrin "subpoena duces tecum", yang oleh Eric W. Springer dikatakan:" "Subpoena which requiring not only that the witness attend but also that he bring to the court certain books, documents, papers or records described in the subpoena".

Dilain hal ditengah maraknya pandemi Corona Virus Disease-19 (Selanjutnya disebut dengan Covid 19) di Indonesia yang sampai dengan saat tulisan ini dibuat penderita Covid 19 yang terpapar di Indonesia mencapai angka 977.474 dengan korban meninggal sebanyak 27.664 jiwa. ${ }^{10}$ secara tidak langsung memperlihatkan problematika dimasyarakat, dengan seringkali identitas penderita atau orang yang telah terpapar Covid 19 diketahui oleh masyarakat di lingkunganya, yang berimplikasi pada diasingkannya penderita tersebut dari masyarakat sekitar. Sering terjadi juga bocornya identitas pasien Covid-19 dimasyarakat lingkungan sekitar yang diakibatkan informasi yang keluar dari pihak rumah sakit dengan tujuan pencegahan penyebaran virus tersebut yang pada dasarnya melanggar ketentuan mengenai privasi pasien penderita Covid 19, maka dari itu perlu dirumuskan bagaimana seharusnya pengaturan mengenai perlindungan terhadap rekam medis kedepannya melihat kondisi Covid 19 saat ini.

\section{DISCUSSION}

Mengenai kepemilikan rekam medis diatur di dalam Undang-Undang Nomor 29 Tahun 2004 Tentang Praktik Kedokteran dan Permenkes Nomor 269 Tahun 2008 Tentang Rekam Medis yang di dalamnya dinyatakan bahwa berkas rekam medis secara fisik merupakan milik Sarana Pelayanan Kesehatan (Saryankes) dan isi berkas rekam medis merupakan milik pasien. ${ }^{11}$ Sejauh pemahaman peneliti yang masih terbatas ini landasan yang dijadikan sebagai dasar pengaturan hukum terkait kepemilikan isi rekam medis di dalam undang-undang masih belum jelas. Namun, tidak menutup kemungkinan bahwa pengaturan tersebut mengacu kepada hasil keputusan hakim atas perkara $W$ allace vs University Hospital of Cleveland di Ohio pada tahun 1959. Keputusan tersebut menyatakan bahwa pasien memiliki hak milik atas informasi medis dirinya yang tercatat di dalam berkas rekam medis dan termasuk pula mengakses serta meminta salinan atas informasi tersebut. $^{12}$

\footnotetext{
${ }^{9}$ Yatini, Purwadi, and Hartiwiningsih.

${ }^{10}$ Sri Pujiningsih, 'Policy Polemic for Covid 19 and Efforts to Handling Information Technology', Journal of Morality and Legal Culture (JMCL), 1.2 (2020), 93-102 <https://doi.org/10.20961/jmail.17i1.41087>.

11 Lihat Pasal 47 ayat 1 Undang-Undang Nomor 29 Tahun 2004 Tentang Praktik Kedokteran. Lihat juga Pasal 12 ayat 1 dan 2 Permenkes Nomor 269 Tahun 2008 Tentang Rekam Medis

12 Otih Handayani, 'Implementation of Prudential Principles in the Use of Disinfectants as an Effort to Prevent Covid-19 Pandemic for Legal Protection of Ecosystems', Journal of Morality and Legal Culture (JMCL), 1.1 (2020), 58-65 <https://doi.org/10.20961/jmail.17i1.41087>.
} 
Salah satu pokok-pokok pikiran UUD 1945 menyatakan bahwa negara melindungi segenap bangsa Indonesia dan seluruh tumpah darah Indonesia dengan berdasar atas persatuan dengan mewujudkan keadilan sosial bagi seluruh rakyat Indonesia. ${ }^{13}$ Salah satu wujud dari pokok pikiran tersebut adalah negara memberikan perlindungan terhadap hak milik warga negara. Ketentuan dalam Pasal 28H ayat 4 UUD 1945 menyebutkan bahwa setiap orang berhak mempunyai hak milik pribadi dan hak milik tersebut tidak boleh diambil secara sewenang-wenang oleh siapapun.

Dalam konteks hak milik, sebagaimana diketahui bersama hal tersebut diatur dalam Hukum Perdata (BW) yang menurut Aturan Peralihan di dalam UUD 1945 tetap dinyatakan berlaku sebelum digantikan oleh undang-undang baru meskipun Indonesia telah merdeka. Pasal 570 BW mengatur mengenai kewenangan dan pembatasan bagi pemegang hak milik yang tentu saja ketentuan tersebut berlaku pula terhadap kepemilikan isi rekam medis. Berdasarkan pemaparan tersebut maka dapat dipahami bahwa kelalaian dalam memenuhi kewajiban untuk menjaga informasi di dalam rekam medis pasien tidak hanya merenggut hak privasi pasien tetapi juga hak milik pasien. Tidak hanya sebatas itu, mengakses dan menggunakan isi rekam medis tanpa persetujuan pasien seharusnya dapat pula dipandang sebagai bentuk pelanggaran terhadap hak milik pasien. Hingga saat ini peraturan hukum yang ada masih belum secara jelas mengatur kewenangan dan batasan terhadap hak milik pasien atas isi rekam medis. Termasuk pula belum diatur bagaimana akibat hukum yang ditimbulkan ketika terjadi pelanggaran yang menimbulkan gangguan terhadap hak milik pasien tersebut. Atas dasar itulah maka dipandang perlu untuk mengkaji persoalan hak milik pasien atas isi rekam medis tersebut menurut perspektif BW. ${ }^{14}$

Beragam pandangan mengenai rekam medis, namun dalam hal ini penulis meminjam istilah dari Edna K. Huffman, yang dikutip Ery Rustiyanto. Dimana menyatakan bahwasanya rekam medis tidak lain merupakan sebuah fakta yang berkaitan dengan keadaan pasien, riwayat penyakit, dan pengobatan masa lalu serta saat ini yang tertulis oleh profesi kesehatan yang memberikan pelayanan kesehatan kepada pasien tersebut. Jusuf Hanafiah dan Amri Amir dengan redaksional yang sedikit lebih rinci juga menjelaskan bahwa rekam medis merupakan sekumpulan keterangan berupa identitas, anamnesa, hasil pemeriksaan laboratorium, hasil pemeriksaan fisik, diagnosa, tindakan medis, dan catatan segala kegiatan pelayanan kesehatan, baik itu pelayanan rawat jalan, rawat inap, atau pelayanan kegawatdaruratan atas pasien dari waktu ke waktu. Permenkes Nomor 269 Tahun 2008 Tentang Rekam Medis juga menjelaskan pula bahwa rekam medis merupakan berkas yang berisikan catatan dan dokumen tentang identitas pasien, pemeriksaan, pengobatan, dan tindakan dan pelayanan lain yang telah diberikan kepada pasien.

Guwandi menjelaskan bahwa secara umum di dalam rekam medis yang lengkap memuat empat jenis data. Jenis data pertama adalah data pribadi yang terdiri dari nama, nomor identitas, tempat/tanggal lahir, jenis kelamin, status pernikahan, alamat, pekerjaan, nama tenaga kesehatan yang merawat, dan informasi lainnya yang dibutuhkan dalam proses identifikasi. Terdapat pula data finansial yang di dalamnya mencakup nama

${ }^{13}$ Hernindyo Reinan Mahastoro and Albertus Sentot Sudarwanto, 'PERTANGGUNGJAWABAN HUKUM PENGURUS YAYASAN TERHADAP RUMAH SAKIT YANG DIKELOLA OLEH YAYASAN', Jurnal Pasca Sarjana Hukum UNS, VII.2 (2019), 212-18.

${ }^{14}$ Muryani. 
perusahaan, perusahaan asuransi yang menanggung biaya pelayanan kesehatan, jenis asuransi, dan nomor polis asuransi. Jenis data berikutnya adalah data sosial yang menyangkut kehidupan sosial pasien seperti kewarganegaraan/kebangsaan, keturunan, hubungan keluarga, penghidupan, kegiatan masyarakat, dan informasi lainnya. Kemudian, jenis data terakhir adalah data medis yang isi memuat hasil-hasil pemeriksaan fisik, riwayat penyakit, pengobatan yang diberikan, progress perawatan, instruksi tenaga kesehatan yang merawat, laporan pemeriksaan laboratorium, dan catatan lainnya seperti hasil konsultasi, laporan anestesi, laporan operasi, lembaran informed consent, catatan perawat, serta catatan-catatan lainnya yang terjadi selama pasien menjalani perawatan dan pengobatan. ${ }^{15}$

Pengisian rekam medis harus dilakukan secara lengkap dan langsung tepat pada waktunya karena apabila pegisian ditunda-tunda maka besar kemungkinan dokter akan lupa dengan setiap kasus dari setiap pasien yang telah dirawatnya, terlebih lagi apabila jumlah pasien tidak sedikit dalam setiap harinya. Tentu saja, hal tersebut dilakukan bukan tanpa alasan mengingat tujuan dibuatnya rekam medis adalah untuk menunjang tercapainya tertib administrasi dalam rangka untuk meningkatkan pelayanan kesehatan di rumah sakit. Selain itu, pembuatan rekam medis di rumah sakit juga bertujuan untuk mendapatkan catatan atau dokumen yang akurat dan informatif dari pasien terkait kehidupan dan riwayat kesehatan, riwayat penyakit di masa lalu dan sekarang, dan pengobatan yang telah diberikan. Dengan kata lain, catatan yang didokumentasikan di dalam rekam medis tersebut dapat memberikan gambaran terkait setiap urutan upaya kesehatan yang dibutuhkan dalam praktik medis. Pada akhirnya, bagaimana kualitas dari rekam medis di suatu Saryankes secara tidak langsung akan mencerminkan pula bagaimana derajat mutu dan kualitas pelayanan kesehatannya. ${ }^{16}$

Rekam medis memiliki nilai guna bagi pasien, Saryankes, dan pemberi pelayanan kesehatan. Nilai guna rekam medis bagi pasien beberapa di antaranya adalah untuk menyediakan bukti tindakan medis yang diterima oleh pasien, memberikan informasi yang akan memudahkan pasien pada kunjungan berikutnya, dan melindungi kepentingan hukum pasien dalam hal apabila terjadi kecelakaan kerja atau bahkan malpraktik. Sementara itu, bagi fasilitas layanan kesehatan rekam medis memiliki nilai guna untuk sebagai data bagi tenaga kesehatan profesional dalam menjalankan tugasnya, bukti atas biaya pelayanan kesehatan yang telah diberikan kepada pasien, dan evaluasi pemanfaatan sumber daya seperti pemakaian bahan dan obat-obatan selama pelayanan kesehatan dilakukan. Kemudian, nilai guna rekam medis bagi pemberi pelayanan adalah untuk memberikan informasi kepada seluruh tenaga kesehatan profesional dalam memberikan pelayanan kesehatan bagi pasien, memberikan data pelayanan kesehatan yang berkesinambungan, dan menyuguhkan data yang bermanfaat untuk penelitian dan pendidikan. ${ }^{17}$ Pendokumentasian isi rekam medis ini secara umum memiliki beberapa kegunaan yang dapat dijabarkan sebagai berikut:

\footnotetext{
${ }^{15} \mathrm{~N}$ W Afreeportamara and Pujiyono, 'Hambatan Kurator Dalam Menyelesaikan Piutang Koperasi Yang Diputus Pailit', Jurnal Hukum Dan Pembangunan Ekonomi, $7.2 \quad$ (2019), 243-50 <https://jurnal.uns.ac.id/hpe/article/view/43014>.

16 Muhammad Jihadul Hayat, 'Historisitas Dan Tujuan Usia Minimal Perkawinan Dalam PerundangUndangan Keluarga Muslim Indonesia Dan Negara Muslim', Journal Equitable, 3.1 (2018), 49-63.

17 Ahmad Kodir Jailani Tanjung, Hari Purwadi, and Hartiwiningsih, 'Paradigma Hakim Dalam Memutuskan

Perkara Pidana Di Indonesia’, Jurnal Pasca Sarjana Hukum UNS, $7.1 \quad$ (2019), 39-51 <https://jurnal.uns.ac.id/hpe/article/view/29178>.
} 
1. Isi rekam medis sebagai sarana komunikasi yang efisien di antara sesama tenaga kesehatan yang ikut memberikan pelayanan kepada pasien terkait penyakit, perkembangan penyakit, terapi yang telah diberikan, dan hal lainnya yang dilakukan selama memberikan pelayanan terhadap pasien;

2. Informasi yang termuat di dalam rekam medis tersebut dapat ditentukan dasar untuk perencanaan pengobatan/perawatan selanjutnya kepada pasien;

3. Setiap informasi yang terdokumentasi di dalam rekam medis selain untuk sarana komunikasi dapat berguna pula sebagai bukti tertulis untuk laporan dan pertanggungjawaban ketika dilakukan audit medis;

4. Isi yang termuat di dalam rekam medis tersebut dapat dijadikan sebagai tolak ukur untuk menganalisis dan mengevaluasi mutu pelayanan yang diberikan oleh sebuah fasilitas kesehatan kepada pasien;

5. Rekam medis berguna untuk melindungi kepentingan hukum bagi pasien, fasilitas kesehatan, dan tenaga kesehatan yang terlibat di dalam upaya pelayanan yang diberikan kepada pasien apabila terjadi permasalahan hukum di kemudian hari;

6. Informasi yang termuat di dalam rekam medis memiliki kegunaan untuk kepentingan pendidikan ataupun penelitian;

7. Rekam medis memiliki fungsi finansial yang dimana berdasarkan informasi yang termuat di dalamnya berguna sebagai dasar penghitungan tarif pembayaran atas pelayanan yang telah diberikan kepada pasien.

Berkaitan dengan kepemilikan rekam medis di dalam Undang-Undang Nomor 29 Tahun 2004 Tentang Praktik Kedokteran pada Pasal 47 ayat 1 dinyatakan bahwa dokumen rekam medis merupakan milik dokter, dokter gigi, dan sarana pelayanan kesehatan sedangkan isi rekam medis merupakan milik pasien. Mengenai hal yang sama juga dijelaskan di dalam Permenkes Nomor 269 Tahun 2008 Pasal 12 ayat 1 dan 2. Selanjutnya, Pasal 12 ayat 3 dan 4 menjelaskan bahwa isi rekam medis yang menjadi milik pasien tersebut adalah berupa ringkasan rekam medis yang secara teknis dapat diberikan, dicatat, dan disalin oleh pasien atau orang lain yang sudah diberikan kuasa atau mendapatkan persetujuan dari pasien. Berdasarkan ketentuan-ketentuan hukum di atas dapat dipahami bahwa berkas fisik rekam medis harus berada di Saryankes. Sementara itu, isi yang termuat di dalam berkas fisik rekam medis berupa identitas, anamnesis, pemeriksaan fisik, pemeriksaan penunjang, dan pengobatan merupakan milik pasien. Hanya saja hingga saat ini masih sering menjadi perdebatan terkait informasi mana sajakah yang seharusnya diberikan kepada pasien sebagai konsekuensi dari ketentuan-ketentuan hukum positif terkait kepemilikan rekam medis tersebut. Oleh karena itu, pembuatan ringkasan medis atau resume medis dilakukan sebagai jalan tengah untuk memenuhi keinginan dan sekaligus hak pasien atas isi rekam medis yang merupakan miliknya. ${ }^{18}$

Isi rekam medis adalah milik pasien dan berisi informasi mengenai hal pribadi dan kesehatan pasien. Saryankes di sisi lain juga memiliki hak milik atas dokumen rekam medis tersebut sehingga berkas fisik rekam medis tersebut harus disimpan di Saryankes. Dengan demikian, berkas rekam medis tidak boleh dibawa oleh pasien dan apabila hilang atau

18 Arif Dian Santoso, Adi Sulistiyono, and Isharyanto, 'Majelis Kehormatan Disiplin Kedokteran Indonesia ( Mkdki ) Untuk Dapat Menjamin Keadilan Dalam Hubungan Dokter Dan Pasien', Jurnal Pasca Sarjana Hukum UNS, VII.1 (2019), 29-38. 
terjadi sesuatu maka menjadi tanggung jawab rumah sakit sebagai Saryankes. ${ }^{19}$ Adanya status kepemilikan atas isi rekam medis tersebut maka dengan kata lain pasien menitipkan milik pribadinya, berupa informasi pribadi dan kesehatan yang tersimpan di dalam berkas rekam medis, kepada Saryankes dan kepada tenaga kesehatan yang memiliki kewenangan untuk mengaksesnya.

Hal tersebut menimbulkan konsekuensi moral dan hukum bagi Saryankes dan tenaga kesehatan yang juga turut andil dalam memberikan pelayanan kesehatan untuk selalu menjaga informasi pasien di dalam rekam medis tersebut. Informasi pasien tersebut harus dijaga agar tidak digunakan tanpa persetujuan dari pasien oleh pihak-pihak yang tidak berkewenangan dan berkepentingan. Oleh karena itu, akses terhadap informasi mengenai pasien harus dibatasi dan hanya dapat digunakan untuk kepentingan pasien dan kepentingan umum yang sebagaimana telah diatur dalam peraturan hukum. Untuk menjamin kepentingan tersebut maka negara ikut andil dengan melakukan pengaturan melalui hukum positif yang sejauh ini masih dalam bentuk peraturan-peraturan hukum terkait kewajiban menjaga rahasia medis pasien. Secara filosofis pengaturan tersebut lebih menekankan kepada perlindungan terhadap hak privasi pasien dan belum terlalu mengarah terhadap perlindungan isi rekam medis yang merupakan milik pasien. Namun sebagaimana diketahui pengaturan mengenai kepentingan umum tersebut belum secara lugas dan tegas diuraikan dalam bentuk hukum positif Indonesia, berdasarkan uraian penulis pada pembahasan sebelumnya pengaturan tersebut diatur dalam Pasal $57 \mathrm{UU}$ Kesehatan yang didalam menyatakan bahwa, ketentuan mengenai hak atas rahasia kondisi kesehatan pribadi sebagaimana dimaksud pada ayat (1) tidak berlaku dalam hal:

1. perintah undang-undang;

2. perintah pengadilan;

3. izin yang bersangkutan;

4. kepentingan masyarakat; atau

5. kepentingan orang tersebut.

Pertanyaannya kemudian adalah dalam 5 (lima) kondisi yang memperbolehkan dibukanya rekam medis pasien penderita Covid-19 di atas, dalam konteks kekinian, dalam hal apa kebocoran tersebut dapat terjadi. Sebagaimana yang penulis jabarkan pada awal pembahasan maka kesimpulan mengenai kebocoran data atau rekam medis pasien tersebut selalu dihubung-hubungkan dengan point $d$ terkait dengan kepentingan masyarakat. Akan tetapi kepentingan masyarakat yang seperti apa, hal tersebut layak untuk dipertanyakan mengingat sejauh ini hal pengaturan dalam hal tersebut terkesan abstrak. Belum ada peraturan turunan ataupun peraturan dalam level Undang-Undang yang mengatur mengenai defenisi kepentingan masyarakat dan indikator-indikator dalam hal membuka rekam medis pasien. ${ }^{20}$

Roscoe Pound dalam pemikiran Sociological Jurisprudence menyatakan bahwa tugas hukum adalah sebagai alat untuk merekayasa masyarakat (Social Engineering). Adapun salah satu fungsi hukum di dalam konsep Social Engineering tersebut adalah untuk melindungi kepentingan-kepentingan manusia secara seimbang. Hakikat keadilan yang dicita-citakan

${ }^{19}$ Rian Saputra and Resti Dian Luthviati, 'Institutionalization of the Approval Principle of Majority Creditors for Bankruptcy Decisions in Bankruptcy Act Reform Efforts', Journal of Morality and Legal Culture (JMCL), 1.2 (2020), 93-102 <https://doi.org/10.20961/jmail.17i1.41087>.

${ }^{20}$ Santoso, Sulistiyono, and Isharyanto. 
oleh hukum hanya akan tercapai apabila terdapat keseimbangan yang harmonis dari kepentingan-kepentingan tersebut. Dengan demikian, kepentingan-kepentingan manusia tersebut harus sedapat dipenuhi dan dilindungi oleh hukum. ${ }^{21}$ Menurut Pound terdapat tiga macam kepentingan yang harus dilindungi oleh hukum. Kepentingan-kepentingan tersebut di antaranya adalah Kepentingan Umum (Public Interest), Kepentingan Masyarakat (Social Interest), dan Kepentingan Individual (Private Interest). Elemen kepentingan individual meliputi kepentingan pribadi/fisik seperti kebebasan/kemauan, kehormatan, privasi, kepercayaan, dan pendapat. Selain itu, kepentingan individual ini juga berkaitan pula dengan hubungan domestik seseorang seperti halnya hubungan dirinya dengan orang tua, anak, dan suami/istri. Kemudian, ada pula kepentingan individual yang bersifat substantif yang berkaitan dengan hak milik, kontrak, keuntungan, pembagian, dan hubungan seseorang dengan orang lain. ${ }^{22}$

Isi rekam medis berisi informasi mengenai kehidupan pribadi, kehidupan sosial, kondisi finansial, dan kondisi medis pasien. Ketika informasi tersebut diketahui dan dimanfaatkan oleh pihak-pihak yang tidak berkepentingan dalam pelayanan kesehatan maka tentu saja hal tersebut akan mengusik kepribadian dan merendahkan kehormatan pasien. Merupakan hal yang wajar apabila terdapat tuntutan dari pasien agar informasiinformasi tersebut dijaga keberadaanya oleh tenaga kesehatan yang merawatnya dan bahkan oleh Saryankes dimana ia mendapatkan perawatan tersebut. Apabila dikaitkan dengan fungsi hukum yang dikemukakan oleh Roscoe Pound maka dapat dikatakan bahwa perlindungan terhadap isi rekam medis pasien merupakan salah satu wujud dari kepentingan individual yang harus dilindungi oleh hukum. Melindungi keberadaan informasi di dalam rekam medis tersebut akan berdampak pula terhadap perlindungan bagi kebebasan, kehormatan, dan privasi pasien. ${ }^{23}$

Pada pembahasan sebelumnya telah dinyatakan bahwa isi rekam medis merupakan milik pasien. Apa yang menjadi dasar pemikiran bahwa isi rekam merupakan milik pasien tersebut tentu perlu dijawab melalui penelusuran dan refleksi pemikiran-pemikiran filosofis terkait hak milik itu sendiri. Roscoe Pound dalam pemikirannya mengenai hak milik mengemukakan bahwa hak milik dalam arti seluas-luasnya tidak hanya sebatas hak milik atas sesuatu yang berwujud tetapi juga meliputi hak milik atas sesuatu yang tak berwujud (incorporeal property). Hak milik merupakan hak pangkal (originair recht) yang oleh karenanya dapat menimbulkan hak-hak lain yang merupakan hak turunan (afgeleide rechten) dari hak milik tersebut. Terdapat beberapa teori yang dapat digunakan untuk memberikan pemahaman secara rasional tentang milik pribadi sebagai lembaga sosial dan lembaga hukum. Satu di antaranya adalah teori Hukum Kodrat. ${ }^{24}$

Grotius di dalam teori Hukum Kodrat menjelaskan mengenai teori hak sempurna dan tidak sempurna. Ia membedakan antara hak milik pribadi dan apa yang menjadi bagian dari pribadi seseorang atau yang disebut sebagai Suum (miliknya) di dalam teorinya

\footnotetext{
${ }^{21}$ Hersriavita.

22 Prasetyo Ade Witoko and Ambar Budhisulistyawati, 'Penyelundupan Hukum Perkawianan Beda Aagama Di Indonesia', Jurnal Hukum Dan Pembangunan Ekonomi, 7.2 (2019), 251-57.

23 I Gusti Ayu Ketut Rachmi Handayani, Lego Karjoko, and Abdul Kadir Jaelani, 'Model Pelaksanaan Putusan Mahkamah Konstitusi Yang Eksekutabilitas Dalam Pengujian Peraturan Perundang-Undangan Di Indonesia', Bestuur, 7.1 (2019), 36-46.

24 Ayu Dian Pratiwi and Pius Triwahyudi, Jaminan Perlindungan Yang Berkeadilan Bagi Tenaga Kerja Difabel Akibat Kecelakaan Kerja', Bestuur, 7.2 (2020), 66 <https://doi.org/10.20961/bestuur.v7i2.40407>.
} 
tersebut. ${ }^{25}$ Grotius menjelaskan bahwaSuum tersebut mencakup kehidupan, anggota tubuh, kebebasan, nama baik,reputasi, dan kehormatan seseorang. Suum merupakan satusatunya hal yang masih dimiliki oleh seseorang secara bebas sekalipun ia tak memiliki satu pun harta benda sebagai milik pribadi. ${ }^{26}$

Menurut Grotius Suumada sebelum pengaturan di dalam hukum positif dilakukan karena keberadaannya ditetapkan oleh Hukum Kodrat sehingga Suum harus dilindungi, dihargai, dan dijamin keberadaannya. Pemikiran tersebut menimbulkan konsekuensi bahwa Suum tidak boleh direnggut dan oleh karena itulah maka setiap pelanggaran terhadap Suum akan dianggap sebagai suatu ketidakadilan. Iadalam pemikirannya tersebut bukan bermaksud ingin menyatakan bahwa keadilan hanya melindungi Suum semata. Namun, sebagaimana di dalam aturan mengenai keadilan di dalam teori hukum alamia mengemukakan bahwa, "Jangan biarkan siapa pun mengambil hak milik yang telah dijadikan barang milik orang lain". Oleh karena itu, konsep keadilan dalam pemikiran Grotius tersebut secara konkret mewujud dalam bentuk sikap menahan diri agar tidak melanggar keberadaanSuum dan barang milik pribadi orang.

Aturan mengenai keadilan menurut Grotius menentukan apa-apa yang menjadi hak setiap individu. Konsekuensinya adalah setiap orang berhak menuntut dan mengklaim hak individu tersebut serta memaksa orang lain untuk menghargainya. Hak seseorang agar seseorang menghargai hak milik pribadi dan Suum yang melekat pada dirinya tersebutmerupakan hak sempurna (perfect rights) yang melahirkan keadilan yang tepat atau ketat. Hak tersebut merupakan hak eksklusif yang mengandung pengertian bahwa pemilik barang itu memiliki kekuasaan untuk mempertahankan dan menggunakannya secara eksklusif dengan tidak memberi kemungkinan bagi orang lain untuk menuntut hak yang sama atas barang tersebut. Hak Sempurna ini berkaitan dengan keadilan ekspletif yaitu keadilan yang disebut oleh Aristoteles dan Adam Smith sebagai keadilan kumulatif yang mengatur jaminan atas hak sempurna setiap orang dan memberi wewenang kepada negara untuk campur tangan dalam menjamin hak-hak tersebut.

Terdapat pula aturan keadilan jenis kedua yang oleh Grotius disebut sebagai hak tidak sempurna (imperfect rights) yangdimana aturan tersebut menyangkut kualitas moral yang tidak bisa dituntut oleh siapapun. Hak ini tidak sepenuhnya disebut sebagai hak dalam arti yang sebenarnya karena orang lain tidak bisa dituntut untuk menghormati hak tersebut. Hak tidak sempurna berkaitan dengan hak atributif atau dikenal pula dengan keadilan distributif. Jenis keadilan ini berkaitan erat dengan kemurahan hati atau semacamnya sehingga keadilan tersebut tidak bersifat memaksakarena diserahkan kepada kemauan baik setiap orang. ${ }^{27}$

Perlu dipahami bahwa isi rekam medis tidak hanya berisi informasi medis terkait kondisi fisik pasien semata. Pada situasi tertentu tidak jarang kondisi kejiwaan pasien perlu didokumentasikan agar menjadi catatan khusus sebagai bahan pertimbangan ketika memberikan upaya pengobatan tertentu bagi pasien. Terlebih lagi pada pelayanan kesehatan yang berkaitan dengan dengan kesehatan jiwa tentu akan lebih banyak ditemukan informasi terkait kondisi kejiwaan pasien. Selain informasi terkait kesehatan

25 A. Sonny Keraf, 2001, Hukum Kodrat Dan Teori Hak Milik Pribadi, Yogyakarta: Kanisius, hlm. 61

${ }^{26}$ I Dewa Made Suartha, 'Criminal Policy Formulation on Regulation of Death Penalties for Criminal Actors', Journal of Morality and Legal Culture (JMCL), 1.1 (2020), 12-17 <https://doi.org/10.20961/jmail.17i1.41087>.

27 Mustika Larasati and Arief Suryono, 'TINJAUAN YURIDIS ASURANSI JIWA TERHADAP KESELAMATAN', Jurnal Pasca Sarjana Hukum UNS, VII.2 (2019), 236-42. 
pasien, isi rekam medis memuat pula informasi mengenai kehidupan pribadi, kehidupan sosial, dan kondisi finansial pasien. Dengan demikian, tidak salah apabila dinyatakan bahwa isi rekam medis dapat memberikan gambaran mengenai kepribadian dan kehidupan pasien. Secara etis pada isi rekam medis melekat nama baik dan kehormatan pasien yang tentu saja akan terusik apabila informasi di dalam rekam medis tersebut diketahui dan dimanfaatkan oleh pihak-pihak yang tidak berwenang dan berkepentingan.

Berdasarkan penjelasan di atas maka dapat dikatakan bahwa isi rekam medis pasien merupakan Suum karena informasi di dalam rekam medis tersebut mencakup kehidupan, anggota tubuh, nama baik, dan bahkan kehormatan pasien. Pemahaman tersebut menimbulkan konsekuensi moral berupa adanya kewajiban untuk melindungi, menghargai, dan menjamin keberadaan isi rekam medis sebagai Suum. Mereka yang dianggap wajib memenuhi kewajiban-kewajiban tersebut adalah tenaga kesehatan dan pihak-pihak yang berkewenagan dan berkepentingan untuk mengakses dan mengetahui isi rekam medis pasien. Akibatnya, mengakses dan menggunakan informasi di dalam rekam medis tanpa persetujuan pasien merupakan wujud ketidakadilan terhadap diri pasien. Atas dasar itulah mengapa isi rekam medis pasien harus dilindungi, dihargai, dan dijamin keberadaannya oleh Hukum Kodrat agar hak milik pasien tersebut tidak direnggut.

Pernyataan di atas tentu akan menimbulkan suatu pertanyaan, Apakah hak tidak sempurna dapat melindungi, menghargai, dan menjamin Suum pasien? Berbicara mengenai kemauan baik erat kaitannya dengan aspek moral di dalam diri manusia yang kelak akan menjiwai perilakunya secara nyata. Bertens menyatakan bahwa sikap moral setiap individu dipengaruhi oleh rasio dan hati nuraninya. Sikap moral tersebut didasari oleh kesadaran moral yang beragam bagi setiap individu. Dasarnya, setiap individu memiliki kemampuan menggunakan rasio dan pengetahuan moral yang berbeda-beda dikarenakan adanya latar belakang pembinaan hati nurani yang berbeda-beda pula. ${ }^{28}$ Dengan kata lain, tidak semua manusia memiliki kesadaran moral yang akan mendorong dirinya untuk menghormati hakhak orang lain. Oleh karena itu, mengandalkan semata kepada kemauan baik masyarakatdalam upaya melindungi, menghargai, dan menjamin isi rekam medis justru akan lebih berpotensi menimbulkan ketidakadilan bagi pasien. Atas dasar argumen itulah mengapa hak sempurna yang seharusnya menjadi dasar untuk melindungi isi rekam medis pasien.

Melalui hak sempurna tersebut pasien memiliki kekuasaan untuk mempertahankan dan menggunakan informasi mengenai secara eksklusif. Konsekuensi atas hak tersebut adalah bahwa pasien memiliki kewenangan untuk mengakses isi rekam medis dan memanfaatkannya untuk kepentingan dirinya. Konsekuensi lainnya adalah baik tenaga kesehatan ataupun Saryankes tidak dapat menuntut hak yang sama sebagaimana pasien sehingga kewenangan untuk mengakses isi rekam medis terbatas dan hanya diperkenankan ketika memberikan pelayanan kesehatan kepada pasien. Selain itu, pasien melalui hak tersebut memiliki kewenangan pula untuk membiarkan negara melakukan campur tangan semata untuk menjamin keberadaan hak milik tersebut melalui pengaturan hukum positif. Pengaturan tersebut bertujuan untuk memaksa masyarakat agar menghormati isi rekam medis sebagai Suum pasien. Peneliti berpandangan bahwa konsekuensi logis menempatkan hak sempurna sebagai dasar untuk melindungi hak milik pasien atas isi rekam medis akan

\footnotetext{
${ }^{28}$ Wijiatmo and Supanto.
} 
menimbulkan sifat eksklusif. Sifat tersebut pada akhirnya tentu akan membatasi nilai kemanfaatan isi rekam medis itu sendiri.

Namun berbeda dengan pandangan tersebut, Thomas Aquinas dalam pemikiran Hukum Kodrat mengenai hak milik membedakan dua macam hak milik, yaitu hak memperoleh dan mengurus hak milik dan hak menggunakan milik pribadi. Berkaitan dengan penggunaan milik pribadi, manusia tidak boleh memandang hal tersebut secara eksklusif. Milik pribadi seharusnya secara inklusif dapat digunakan bersama orang lain dan oleh mereka yang membutuhkan. Dengan kata lain, hak milik pribadi memiliki semangat komunal dalam bentuk fungsi sosial. ${ }^{29}$ Fungsi sosial hak milik memiliki tujuan untuk memenuhi kepentingan umum demi mewujudkan kesejahteraan umum (Bonum Commune). Menurut John Rawls, dikutip oleh Kusmaryanto, kesejahteraan umum merupakan kondisi umum yang memberikan keuntungan bagi semua orang. Ia merupakan kebaikan yang bisa dinikmati, disetujui, dan diinginkan oleh semua orang. Kesejahteraan umum memiliki beragam wujud dimana salah satunya berupa sesuatu yang bermanfaat bagi kepentingan bersama. ${ }^{30}$

Berdasarkan pemikiran Aquinas tersebut maka sifat inklusif seharusnya melekat pada hak milik pasien atas isi rekam medis. Sifat inklusif akan melahirkan nilai guna atas isi rekam medis yang tidak hanya bagi kepentingan pasien semata tetapi sifat tersebut juga memperkenankan agar nilai guna tersebut ditujukan untuk kepentingan-kepentingan lain di luar kepentingan pasien. Dengan demikian, isi rekam medis pasien juga memiliki fungsi sosial yang akan memberikan manfaat bagi kepentingan masyarakat luas yang sebagaimana menurut pemikiran Rawls hal tersebut bermanfaat bagi kesejahteraan umum. Beberapa wujud konkret dari fungsi sosial dari hak milik atas isi rekam medis pasien di antaranya dapat berupa:

1. Isi rekam medis dapat digunakan untuk kepentingan penegakan hukum ketika terjadi sengketa medis yang dimana dalam kondisi tersebut diduga terdapat kepentingan masyarakat sebagai pasien yang dirugikan;

2. Isi rekam medis dapat digunakan untuk kepentingan pendidikan dan penelitian guna mengembangkan ilmu pengetahuan yang kelak akan bermanfaat bagi kemaslahatan masyarakat;

3. Isi rekam medis dapat digunakan untuk kepentingan Saryankes, semisal untuk mengklaim asuransi pelayanan kesehatan, sehingga pelayanan kesehatan yang tentu membutuhkan biaya besar dapat terus berjalan dan dapat terus memberikan pelayanan bagi masyarakat.

Fungsi sosial hak milik menurut perspektif etika tidak seharusnya dipandang melalui pola pikir utilitarianisme, ${ }^{31}$ yang hanya menitikberatkan pada kemanfaatan semata karena rentan menimbulkan pengabaian terhadap aspek-aspek etis. Hal itu mengingat bahwa pada informasi pasien yang terdokumentasi di dalam rekam medis secara etis melekat nama baik dan kehormatan pasien. Itulah mengapa fungsi sosial hak milik seharusnya

${ }^{29}$ Febry Wulandari and Waluyo Waluyo, 'Efektivitas Pemanfaatan Dana Bagi Hasil Cukai Hasil Tembakau Dalam Bidang Kesehatan Di Kota Surakarta Tahun 2018', Bestuur, 7.1 (2019), 15-25 <https://doi.org/10.20961/bestuur.v7i1.28418>.

${ }^{30}$ Budiharto Budiharto, Sartika Nanda Lestari, and Gusto Hartanto, 'The Legal Protection of Lenders in Peer To Peer Lending System', Law Reform, 15.2 (2019), 275-89 < https://doi.org/10.14710/lr.v15i2.26186>.

${ }^{31}$ Hersriavita. 
dipandang melalui perspektif etika keutamaan. ${ }^{32}$ Menurut etika keutamaan penerapan fungsi sosial hak milik seharusnya berada pada 'jalan tengah' di antara dua kondisi ekstrim, yaitu antara menempatkan hak milik secara eksklusif dan menempatkan hak milik secara inklusif-utilitarianis. Etika keutamaan memandang bahwa fungsi sosial hak milik memiliki nilai kemanfaatan yang besar selain bagi pemegang hak miliknya sehingga hak milik tersebut dapat dimanfaatkan untuk kepentingan masyarakat luas guna mewujudkan kesejahteraan umum. Namun, bukan berarti pula kemanfaatan yang besar tersebut menjadi alasan pembenar untuk mengesampingkan hak dari pemegang hak milik yang seharusnya tetap dihormati. Melalui perspektif keutamaan tersebut diharapkan dapat tercapai keadilan baik itu bagi pemegang hak milik ataupun bagi masyarakat yang membutuhkan fungsi sosial dari hak milik tersebut.

Berdasarkan pemikiran tersebut maka dapat dinyatakan bahwa isi rekam medis milik pasien seharusnya memiliki fungsi sosial sehingga dapat memberikan nilai kemanfaatan yang besar bagi masyarakat luas. Namun, kemanfaatan yang besar tersebut tidak menjadikan hak pasien sebagai pemilik isi rekam medis diabaikan sehingga tetap harus dihormati. Secara konkret pemikiran tersebut dapat mewujud dalam bentuk adanya persetujuan pendahuluan dari pasien atau adanya kompensasi tertentu bagi pasien ketika isi rekam medis miliknya digunakan untuk kepentingan umum. Agar ketertiban di masyarakat dalam hal pemberdayaan fungsi sosial isi rekam medis milik pasien bagi kesejahteraan umum dapat terjamin maka tentu dibutuhkan peran negara melalui pengaturan di dalam hukum positif.

Dalam hal ini menurut hemat penulis, rekam medis sebagai sebuah hak milik. Maka terhadap hak milik pasien atas isi rekam medis tidak dapat dilakukan pengalihan hak milik seperti halnya dalam hak milik atas kebendaan pada umumnya dan tidak dapat pula dicabut oleh pemerintah demi kepentingan umum. Hal tersebut dikarenakan hak perdata yang melekat pada isi rekam medis tersebut tidak hanya berupa hak milik atas isi rekam medis tetapi terdapat pula hak atas kehormatan pasien sehingga bersifat absolut. Hanya saja karena isi rekam medis memiliki fungsi sosial maka baik masyarakat umum ataupun pemerintah hanya memiliki hak pakai atas isi rekam medis tersebut. Hak pakai tersebut berupa pemanfaatan isi rekam medis untuk alat bukti hukum dalam proses penegakan hukum, untuk kepentingan administrasi dan finansial Saryankes, untuk kepentingan pendidikan dan penelitian, dan untuk kepentingan statistik kesehatan yang akan digunakan sebagai dasar pembuatan kebijakan di bidang kesehatan.

Dalam hal penggunaan hak milik pasien atas isi rekam medis oleh pemerintah maka tidak diperlukan persetujuan dari pasien selama hak-hak pasien lainnya seperti hak atas privasi tetap dihormati. Namun, apabila isi rekam medis tersebut digunakan oleh pihak lain yang tidak berafiliasi dengan pemerintah maka dibutuhkan persetujuan dari pasien sebelum penggunaan atas isi rekam medis tersebut dapat dilakukan. Ketika isi rekam medis pasien digunakan tanpa persetujuan pasien maka hal tersebut dapat dianggap sebagai perbuatan yang merugikan kepentingan pasien. Pada kasus tersebut maka pasien dapat mengajukan gugatan melalui Pasal 1365 BW. Dasar pengajuan gugatan tersebut tidak hanya didasarkan pada pelanggaran atas ketentuan di dalam undang-undang dan

32 Sarjiyat, 'Regional Regulation Implementation of Madiun City Number 45 of 2018 Concerning with Prevention and Enhancement of Slum Housing and Settlement Quality', Journal of Morality and Legal Culture (JMCL), 1.2 (2020), 93-102 <https://doi.org/10.20961/jmail.17i1.41087>. 
ketentuan umum tetapi juga didasarkan pada pelanggaran moral yang mewajibkan bahwa isi rekam medis pasien merupakan Suum seharusnya harus dihormati oleh pihak lain. Dalam konteks Covid-19,33 hal ini cenderung dibutuhkan mengingat dalam hal penanggulangan pandemi Covid-19 pendataan mengenai pasien-pasien penderita Covid-19 dibutuhkan untuk melihat perkembangan dan penyebaran virus secara nasional. ${ }^{34}$ Namun tentunya hal tersebut dilakukan dengan tidak melanggar hak-hak privasi pasien yang dapat merugikan kepentingan pribadi pasien tersebut.

\section{CONCLUSION}

Dilihat dari teori hak milik maka dapat dikatakan bahwasanya rekam medis merupakan milik dari seorang pasien. Hal tersebut menimbulkan konsekuensi moral dan hukum bagi Saryankes dan tenaga kesehatan yang juga turut andil dalam memberikan pelayanan kesehatan untuk selalu menjaga informasi pasien di dalam rekam medis tersebut. Informasi pasien tersebut harus dijaga agar tidak digunakan tanpa persetujuan dari pasien oleh pihak-pihak yang tidak berkewenangan dan berkepentingan. Namun disisi lain, kepemilikan tersebut juga tetap diikuti dengan fungsi sosial didalamnya maka baik masyarakat umum ataupun pemerintah hanya memiliki hak pakai atas isi rekam medis tersebut dalam hal penggunaan hak milik pasien atas isi rekam medis oleh pemerintah maka tidak diperlukan persetujuan dari pasien selama hak-hak pasien lainnya seperti hak atas privasi tetap dihormati. Namun, apabila isi rekam medis tersebut digunakan oleh pihak lain yang tidak berafiliasi dengan pemerintah maka dibutuhkan persetujuan dari pasien sebelum penggunaan atas isi rekam medis tersebut dapat dilakukan, dalam konteks Covid-19, hal ini cenderung dibutuhkan mengingat dalam hal penanggulangan pandemi Covid-19 pendataan mengenai pasien-pasien penderita Covid-19 dibutuhkan untuk melihat perkembangan dan penyebaran virus secara nasional.

\section{REFERENCES}

Afreeportamara, N W, and Pujiyono, 'Hambatan Kurator Dalam Menyelesaikan Piutang Koperasi Yang Diputus Pailit', Jurnal Hukum Dan Pembangunan Ekonomi, 7.2 (2019), 243-50 <https://jurnal.uns.ac.id/hpe/article/view/43014>

Balenina, C.D., 'Partisipasi Masyarakat Dalam Pengelolaan Desa Sampah Mandiri Di Desa Kalisoro, Tawangmangu, Kabupaten Karanganyar', Bestuur, 7.1 (2019), 26-35 $<$ https://jurnal.uns.ac.id/bestuur/article/view/17392>

Budiharto, Budiharto, Sartika Nanda Lestari, and Gusto Hartanto, 'The Legal Protection of Lenders in Peer To Peer Lending System', Law Reform, 15.2 (2019), 275-89 $<$ https://doi.org/10.14710/lr.v15i2.26186>

Giyana, Frenti, 'Analisis Sistem Pengelolaan Rekam Medis Rawat Inap Rumah Sakit

33 Rosidi Ruslan, 'COVID-19 Fulfilling Workers 'Economic Rights Positive', Journal of Morality and Legal Culture (JMCL), 1.2 (2020), 93-102 < https://doi.org/10.20961/jmail.17i1.41087>.

34 Fahmi Hakam, 'Analisis Penyediaan Rekam Medis Pasien Rawat Jalan Berdasarkan Standar Operasional Prosedur (SOP) Di Puskesmas X', Jurnal Manajemen Informasi Dan Administrasi Kesehatan (JMLAK), 1.1 (2018). 
Umum Daerah Kota Semarang,, Jurnal Kesehatan Masyarakat Universitas Diponegoro, 1.2 (2012), 18739

Hakam, Fahmi, 'Analisis Penyediaan Rekam Medis Pasien Rawat Jalan Berdasarkan Standar Operasional Prosedur (SOP) Di Puskesmas X', Jurnal Manajemen Informasi Dan Administrasi Kesehatan (JMLAK), 1.1 (2018)

Handayani, I Gusti Ayu Ketut Rachmi, Lego Karjoko, and Abdul Kadir Jaelani, 'Model Pelaksanaan Putusan Mahkamah Konstitusi Yang Eksekutabilitas Dalam Pengujian Peraturan Perundang-Undangan Di Indonesia', Bestuur, 7.1 (2019), 36-46

Handayani, Otih, 'Implementation of Prudential Principles in the Use of Disinfectants as an Effort to Prevent Covid-19 Pandemic for Legal Protection of Ecosystems', Journal of Morality and Legal Culture ( JMCL ), 1.1 (2020), 58-65 <https://doi.org/10.20961/jmail.17i1.41087>

Hayat, Muhammad Jihadul, 'Historisitas Dan Tujuan Usia Minimal Perkawinan Dalam Perundang-Undangan Keluarga Muslim Indonesia Dan Negara Muslim', Journal Equitable, 3.1 (2018), 49-63

Hersriavita, Sara, 'UPAYA PENGEMBALIAN KERUGIAN NEGARA DARI PERKARA TINDAK PIDANA KORUPSI OLEH KEJAKSAAN NEGERI SUKOHARJO', Jurnal Hukum Dan Pembangunan Ekonomi, 7.1 (2019), 15-28

Larasati, Mustika, and Arief Suryono, 'TINJAUAN YURIDIS ASURANSI JIWA TERHADAP KESELAMATAN', Jurnal Pasca Sarjana Hukum UNS, VII.2 (2019), $236-42$

Mahastoro, Hernindyo Reinan, and Albertus Sentot Sudarwanto, 'PERTANGGUNGJAWABAN HUKUM PENGURUS YAYASAN TERHADAP RUMAH SAKIT YANG DIKELOLA OLEH YAYASAN', Jurnal Pasca Sarjana Hukum UNS, VII.2 (2019), 212-18

Muryani, Eni, 'Sinergisitas Penegakan Hukum Pada Kasus Pertambangan Emas Tanpa Izin Di Kabupaten Banyumas, Jawa Tengah', Bestuur, 7.2 (2019), 84 $<$ https://doi.org/10.20961/bestuur.v7i2.40437>

Nugraha, Riyan Aditya, Widodo Tresno Novianto, and Supanto, 'KARANGANYAR DALAM MEMUTUS PERKARA PIDANA HAK CIPTA GUNA MENCIPTAKAN KEPASTIAN HUKUM CIPTA ( Putusan', Jurnal Pasca Sarjana Hukum UNS, 7.1 (2011), 169-80

Pratiwi, Ayu Dian, and Pius Triwahyudi, 'Jaminan Perlindungan Yang Berkeadilan Bagi Tenaga Kerja Difabel Akibat Kecelakaan Kerja', Bestuur, 7.2 (2020), 66 <https://doi.org/10.20961/bestuur.v7i2.40407>

Pujiningsih, Sri, Policy Polemic for Covid 19 and Efforts to Handling Information Technology', Journal of Morality and Legal Culture (JMCL), 1.2 (2020), 93-102 <https://doi.org/10.20961/jmail.17i1.41087>

Rosidi Ruslan, 'COVID-19 Fulfilling Workers 'Economic Rights Positive', Journal of Morality and Legal Culture (JMCL), 1.2 (2020), 93-102 <https://doi.org/10.20961/jmail.17i1.41087>

Santoso, Arif Dian, Adi Sulistiyono, and Isharyanto, 'Majelis Kehormatan Disiplin Kedokteran Indonesia ( Mkdki) Untuk Dapat Menjamin Keadilan Dalam Hubungan Dokter Dan Pasien', Jurnal Pasca Sarjana Hukum UNS, VII.1 (2019), 29-38

Saputra, Rian, and Resti Dian Luthviati, 'Institutionalization of the Approval Principle of 
Majority Creditors for Bankruptcy Decisions in Bankruptcy Act Reform Efforts', Journal of Morality and Legal Culture (JMCL), 1.2 (2020), 93-102 <https://doi.org/10.20961/jmail.17i1.41087>

Sarjiyat, 'Regional Regulation Implementation of Madiun City Number 45 of 2018 Concerning with Prevention and Enhancement of Slum Housing and Settlement Quality', Journal of Morality and Legal Culture (JMCL), 1.2 (2020), 93-102 <https://doi.org/10.20961/jmail.17i1.41087>

Suartha, I Dewa Made, 'Criminal Policy Formulation on Regulation of Death Penalties for Criminal Actors', Journal of Morality and Legal Culture (JMCL ), 1.1 (2020), 12-17 <https://doi.org/10.20961/jmail.17i1.41087>

Susanto, Gunawa, 'Sistem Informasi Rekam Medis Pada Rumah Sakit Umum Daerah (RSUD) Pacitan Berbasis Web Base', Speed-Sentra Penelitian Engineering Dan Edukasi, $3.4(2012)$

Tanjung, Ahmad Kodir Jailani, Hari Purwadi, and Hartiwiningsih, 'Paradigma Hakim Dalam Memutuskan Perkara Pidana Di Indonesia', Jurnal Pasca Sarjana Hukum UNS, 7.1 (2019), 39-51 <https://jurnal.uns.ac.id/hpe/article/view/29178>

Wijiatmo, and Supanto, 'Kebijakan Hukum Pidana Dalam Memberikan Perlindungan Hukum Terhadap Guru Dalam Hal Kedisplinan', Pasca Sarjana Hukum UNS, 7.1 (2019), 85-92

Witoko, Prasetyo Ade, and Ambar Budhisulistyawati, 'Penyelundupan Hukum Perkawianan Beda Aagama Di Indonesia', Jurnal Hukum Dan Pembangunan Ekonomi, 7.2 (2019), 251-57

Wulandari, Febry, and Waluyo Waluyo, 'Efektivitas Pemanfaatan Dana Bagi Hasil Cukai Hasil Tembakau Dalam Bidang Kesehatan Di Kota Surakarta Tahun 2018, Bestuur, 7.1 (2019), 15-25 <https://doi.org/10.20961/bestuur.v7i1.28418>

Yatini, Hari Purwadi, and Hartiwiningsih, 'Reformulasi Konstruksi Pidana Dalam Menjerat Pelaku Tindak Pidana Korporasi', Pasca Sarjana Hukum UNS, VII.1 (2019), 144-52 